\title{
ПІДВИЩЕННЯ ЕФЕКТИВНОСТІ ОБ'СДНАНИХ ТЕРИТОРІАЛЬНИХ ГРОМАД ЗА РАХУНОК ЇХ СПЕЦАЛІЗАЦЇ̈ В СФЕРІ ТУРИЗМУ ТА ГОТЕЛЬНОГО ГОСПОДАРСТВА
}

Рябєв А.А., канд. екон. наук, доцент

Харківський національний університет міського господарства ім.О.М. Бекетова

Поколодна М.М., к.геогр.н., доцент

Харківський національний університет міського господарства ім. О.М. Бекетова

Абрамов В.В., доцент

Харківський національний університет міського господарства ім. О.М. Бекетова

Постановка проблеми. В останні роки в Україні набувають розповсюдження нові адміністративно-економічні територіальні утворення об'єднані територіальні громади (далі - ОТГ), під якими мають на увазі добровільне об'єднання мешканців декількох розрізнених населених пунктів (сіл, селищ, міст в один адміністративний центр). Після об'єднання створюють новий адміністративний центр (як правило - найбільший населений пункт 3 об'єднаних), а у ньому - нову загальну для всіх об'єднаних населених пунктів раду та інші органи самоврядування.

Аналіз останніх досліджень і публікацій. Проблеми, пов'язані з розвитком туризму в об'єднаних територіальних громадах України та іï регіонів, досліджували вітчизняні вчені О. Сущенко, В. Дубіщев, В. Толкованов, І. Черниш, Т. Журавель, Л. Івашина, Н. Чир, Р. Кочаровський, О. Коваль та ін.

Виділення невирішених раніше частин загальної проблеми. ОТГ формуються відповідно до Закону України «Про добровільне об'єднання територіальних громад» [1]. При цьому слід зазначити, що після створення ОТГ отримують ресурси населених пунктів і відповідні повноваження та переходять на прямі бюджетні відносини із державним бюджетом, не підпорядковуються районній раді, а самі визначають напрями розвитку та на що витрачати зароблені гроші.

Об'єднані громади отримують такі ж доходи, які сьогодні отримують міста обласного значення, адже після об'єднання в бюджеті ОТГ залишається:

- $\quad 60 \%$ податку на доходи фізичних осіб;

- $\quad 100 \%$ податку на майно;

- $\quad 100 \%$ єдиного податку;

- $5 \%$ акцизного податку 3 роздрібної торгівлі (тютюн, алкоголь, нафтопродукти);

- $\quad 100 \%$ податку на прибуток установ комунальної власності ОТГ;

- $\quad 100 \%$ платежів за надання адміністративних послуг; 
- $\quad 25 \%$ екологічного податку [2].

Звідси постає актуальне питання щодо пошуку та формування джерел отримання прибутку ОТГ. Цілком зрозуміло, що виключно традиційних джерел у межах сільського господарства гарантовано не вистачить для забезпечення стійкого розвитку ОТГ. Саме тому доцільним вважається запропонувати у якості одного 3 можливих шляхів розвитку ОТГ розвиток туризму та готельного господарства.

Обгрунтуванням такої пропозиції $\epsilon$ наявність необхідного рекреаційнотуристського потенціалу (під яким розуміється вся сукупність природних, культурно-історичних і соціально-економічних передумов для організації рекреаційної та туристської діяльності на певній території (в нашому випадку в межах ОТГ), які, в свою чергу, можуть стати опорними пунктами для розвитку туристської інфраструктури регіонів [3]).

Формулювання цілей статті. Виходячи 3 невирішеності проблемного питання, необхідно визначити конкретні шляхи розвитку тих видів діяльності, які здатні забезпечити створення готельної інфраструктури та деяких видів туристської та рекреаційної діяльності, що будуть здатні забезпечити прибутковість об'єднаних територіальних громад з урахуванням того факту, що ОТГ будуть переважно орієнтовані на сільський та екологічний туризм.

Виклад основного матеріалу дослідження. Звісно, надання туристськорекреаційних послуг потребує наявності відповідної спеціалізованої інфраструктури. При цьому, кожен із різновидів туризму має власний специфічний набір, який вирізняється своєю складністю будівництва, потребами у спеціальних умовах (зокрема, природного характеру, наприклад, наявність відповідних форм рельєфу тощо), сезонністю функціонування i, відповідно, вартістю створення та подальшого обслуговування. В даному дослідження пропонуємо розглянути саме ті види туризму та рекреаційних занять, які потребують найменших обсягів інвестицій і можуть бути реалізовані за рахунок власних коштів членів ОТГ без залучення інвесторів, що особливо актуально на першому етапі розвитку громади [4-6]. Серед численного різноманіття видів і різновидів туризму до таких, що потребують порівняно незначних інвестицій, можливо віднести екологічний туризм i сільський туризм. Тому пропонуємо зупинитися на розгляді саме цих видів туризму. Крім того, варто зауважити, що обидва вони розглядаються як перспективні для світового та національного туристичного ринку через низку причин і тенденцій, які панують в туристичній спільноті, а саме: туризм стає дедалі екологічно відповідальнішим; має місце відмова від поїздок в овертуристські дестинації; більше туристів планують власну подорож самостійно; відбувається скорочення тривалості подорожей.

Відчуваючи особисту відповідальність, все більше людей замислюються над власним внеском у руйнування оточуючого середовища, через що відмовляються подорожувати літаками на довгі відстані, споживати продукцію, вироблену 3 нанесенням шкоди довкіллю, зупинятися у закладах розміщення та користуватися послугами перевізників i туроператорів, які не дотримуються екологічних 
стандартів та не використовують відповідних технологій. Відмова від одноразового пластику (посуду, соломинок для пиття, одноразових пляшок для шампунів в номерах тощо), утилізація сміття, вуглецева нейтральність - це лише невеликий перелік таких перетворень.

Овертуризм - це перенасиченість туристами окремих напрямків, яка спричинила негативний вплив на історичні та природні пам'ятки, місцевих жителів та їхній спосіб життя. Зазвичай туризм вважається позитивним чинником розвитку локальних економік, проте в занадто популярних місцях завеликий потік туристів перетворився на руйнівну силу. Найвідомішими овертуристськими дестинаціями є Венеція, Париж, Санторіні, Барселона. Натомість туристи планують подорожі в менш відомі напрямки - експерти прогнозують, що 2020 року серед туристів із Західної Свропи, США та Азії зросте зацікавленість у подорожах до країн Східної Свропи [7]. Продовженням цієї тенденції є зростання популярності так званих подорожей з зануренням у атмосферу місцевих мешканців, 3 можливістю спілкування та проживання певний час в їхньому стилі життя, виконання певних видів робіт та навчання традиційним заняттям і промислам.

Тотальна інформаційна доступність дозволяє більш вільно та гнучко планувати власні поїздки, що спонукає все більшу кількість туристів до самостійної організації мандрівок, а також відбиває індивідуалізований туристський попит щодо мети здійснення подорожі. Так, хтось вирушить із дому виключно для «злиття 3 природою», хтось - 3 метою отримати гастрономічні задоволення, когось цікавлять складні випробування себе та отримання нової порції адреналіну від подолання перешкод.

Ще однією тенденцією є скорочення часу подорожей при одночасному збільшенні їх частоти. Уік-енд тури вже впевнено завоювали свою популярність на ринку через низку переваг: порівняно низька вартість подорожі; отримання різноманітних насичених вражень за короткий проміжок часу; можливість швидкого знайомства 3 новим місцевостями; таку відпустку легко вписати у переповнений робочий графік.

Можливості для здійснення подорожей із домашніми тваринами. Дослідження, що наведене на сайті booking.com, показало, що для 55\% опитаних мандрівників домашні улюбленці такі ж важливі, як іхні діти. Так, $42 \%$ клієнтів обирають місце для відпустки в залежності від того, чи можна взяти туди свого улюбленця. У 2020 році тенденція створювати комфортні умови для перебування гостей iз домашніми тваринами буде сприяти заохоченню таких подорожей. Зручності для тварин в готелі, багато активностей для господарів зі своїми улюбленцями, чудовий догляд та їжа у місці відпочинку дозволять подорожам iз тваринами стати легкими та популярними [7].

Усі ці тенденції наочно демонструють і підтверджують перспективність екологічного та сільського туризму в найближчий час, що й обумовлює актуальність їх більш детального розгляду. 
Екологічний туризм - це спеціалізований вид туризму, заснований на потребі туристів у глибокому пізнанні унікального природного та культурного середовища, що здійснюється на природних, у тому числі природоохоронних територіях, і не порушує цілісність відвідуваних екосистем.

Відмінні особливості екологічного туризму:

1) стимулювання та задоволення бажання «спілкуватися з природою»;

2) подорож у природу, причому головний зміст таких подорожей знайомство $з$ живою природою, а також $з$ місцевими звичаями та культурою;

3) запобігання негативному впливу на природу та культуру;

4) зведення до мінімуму негативних наслідків екологічного та соціально-культурного характеру, підтримання екологічної стійкості середовища;

5) сприяння охороні природи та місцевого соціо-культурного середовища;

6) сприяння охороні природних ресурсів;

7) екологічна освіта та просвіта;

8) участь місцевих жителів і отримання ними доходів від туристської діяльності, що створює для них економічні стимули до охорони природи;

9) економічна ефективність i забезпечення соціально-економічного розвитку територій;

10) сприяння сталому розвитку відвідуваних регіонів.

Здебільшого екологічні подорожі проходять по місцевостях, які належать до об'єктів природно-заповідного фонду, та таких, які мало задіяні в людській діяльності (типові та унікальні геотопи), або просто мальовничих місцевостях. Екотуристів приваблюють i унікальні об'єкти неживої природи, геоморфологічні, гідрологічні та інші особливості (окремі гори та каньйони, печери, водоспади, озера та річки), а також палеонтологічні знахідки. Об'єктами екотуризму можуть бути екзотичні рослинні співтовариства та біоценози в цілому, наприклад, тропічні ліси, квітуча тундра влітку або пустеля навесні. Крім цього, об'єктами екотуризму можуть бути культурні, етнографічні, археологічні й історичні пам'ятки, а також природно-антропогенні (культурні) ландшафти в цілому, що особливо характерно для екологічних турів в їх широкому трактуванні. Нерідко в поле зору екотуристів впадають об'єкти та підприємства, які, або дотримуються екологічних норм виробництва продукції (наприклад, фермерські господарства, виробництва 3 оборотними технологіями), або сприяють покращенню стану навколишнього природного середовища (очисні споруди). Таким чином, бачимо, що практично всі місцевості придатні для організації екотуристських маршрутів. Найбільш розповсюдженим і дієвим методом організації екологічного туризму та його провідним інфраструктурним елементом вступає «екологічна стежка», яка дозволяє об'єднати різнорідні екооб'єкти в єдиний цілісний маршрут.

Зазвичай екологічна стежка відвідується організовано під керівництвом екскурсовода. Однак, при наявності спеціально розроблених буклетів- 
путівників, а також аудіогідів, можливо і самостійне ознайомлення [8].

Протяжність екологічної стежки обумовлюється часом, протягом якого може проводитися екскурсія та обраним засобом пересування відвідувачів. Прийнято вважати, що екологічні стежки призначені тільки для пішоходів, але при наявності відповідних природних умов створюються стежки також для водних туристів, лижників, велосипедистів, любителів верхової їзди.

За призначенням на територіях ОТГ найбільш раціональною буде організація прогулянково-пізнавальних екостежок. Прогулянково-пізнавальні екологічні стежки, або стежки «вихідного дня», мають протяжність 4-8 км. Маршрут пролягає переважно по природним охоронюваним місцевостям або місцевостям iз винятковими пейзажними характеристиками. Відпочиваючих об'єднують у групи i під керівництвом екскурсовода або з путівником за 3-4 години вони прогулянковим кроком проходять весь маршрут, знайомлячись 3 природою, пам'ятками історії та культури. В тій чи іншій мірі на таких маршрутах зачіпають питання взаємовідношення природи та людини, впливу господарської діяльності на природу, заходів щодо запобігання небажаних наслідків, значення лісу для городянина, способів зниження шуму тощо.

Крім літніх прогулянково-пізнавальних стежок, можна створювати зимові стежки. Зимовий відпочинок у даний час отримав великий розвиток. Його основною та загальнодоступною формою $\epsilon$ лижні прогулянки. Зимова екологічна стежка також сприяє здійсненню природоохоронних, рекреаційних, інформативно-пізнавальних і виховних завдань. На відміну від літньої стежки, зимова стежка може мати дещо іншу трасу. При виборі основними факторами $\epsilon$ зручність для лижних прогулянок, наявність різних природних об'єктів, зручних для огляду в зимовий час. Необхідно також врахувати більшу швидкість пересування відвідувачів по зимовій стежці в порівнянні 3 літньою стежкою при наявності однієї і тієї ж кількості об'єктів огляду: на лижах швидкість пересування більше, та й розповідь екскурсовода коротше [9].

У цілому при організації екологічної стежки необхідно враховувати три головні вимоги, яким вона повинна задовольняти:

1. Привабливість стежок для відвідувачів складається 3 трьох компонентів: краси природи, іiі своєрідності та різноманітності.

2. Доступність для відвідувачів. Необхідно, щоб екологічна стежка розташовувалася порівняно недалеко від населеного пункту і щоб до ії початку вели хороші під'ізні шляхи: відвідувач не повинен відчувати фізичної та нервової втоми ще до того моменту, як він зробить перший крок по стежці.

3. Інформативність - здатність задовольняти пізнавальні потреби людей в області географічних, біологічних, екологічних та інших проблем.

Устаткування екологічної стежки складається 3 двох великих етапів - це: прокладка на місцевості маршруту стежки та комплектація стежки необхідними об'єктами, які вимагають окремого розгляду; оволодіння відповідними знаннями та методикою. Основними інвестиціями при організації екологічної стежки $є$ iï обладнання, найпоширенішим елементами якого є: інформаційні щити на кожній 
точці-зупинці, стовпчики-покажчики, оглядові майданчики та вежі, рекреаційні пункти, санітарні елементи (туалети, сміттєві баки тощо).

Підготовка екскурсоводів для роботи на екологічних стежках вимагає певної кваліфікації. Навіть досвідченому екскурсоводові це не завжди вдається зробити вдало, так як природа дуже динамічна та демонстрація деяких об'єктів або явищ (сліди тварин, фенофази рослин, атмосферні процеси та ін.) вимагає від екскурсовода постійної готовності до їх появи або зникнення, широкої ерудиції та спостережливості, відмінного знання місцевих умов.

В організації екскурсій по екологічній стежці велике значення має попереднє інформування учасників про характер перешкод на маршруті, його протяжність, необхідне спорядження, пам'ятки маршруту, особливості природоохоронного режиму в його зоні.

Невелика чисельність групи диктується також вимогам техніки безпеки, яких необхідно строго дотримуватися в умовах природного середовища. Тому всю групу, яка прибула до стежки автобусом або поїздом, слід розділити на підгрупи чисельністю до 15 осіб, в кожній з яких працює свій екскурсовод-інструктор [10].

Іншим доступним для організації елементом інфраструктурного забезпечення є такий, що дозволяє додати атрактивності відвідуваній місцевості, задовольняє екологічним вимогами та надає адреналіну відвідувачам, - зіплайн. Zip-Line або троллей - це один із сучасних популярних видів розваг для дорослих і дітей, який являє собою спуск по круто натягнутому тросу або мотузці за допомогою блоку або карабіна. Довжина троллеїв сягає від 100 метрів до 3-4 кілометрів, а швидкість становить 30-110 км/год. [11]. При правильній технічній організації, підготовці персоналу й якісному обслуговуванні зіплайни прості у використанні та безпечні. Вони отримали розповсюдження у всіх частинах світу. Наприклад, у США функціонує 200 комерційних зіплайнів i 13000 приватних троллеїв. Найдовший зіплайн знаходиться в Парк-де-Авентура Барранкас-дель Кобрі в Мексиці: його довжина становить 2545 метрів. Найкрутіший зіплайн розташований у Непалі: у ZipFlyer ухил становить аж 56 градусів. До речі, ця ж лінія є другою за висотою - цілих 610 метрів. 19 вересня 2015 року було відкрито найкрутіший зіплайн в Свропі (в Планіція, Словенія): його довжина 566 метрів; перепад висот становить 202 метра; середній кут нахилу 38,33 градуса, а максимальний - 58,6 градусів [12]. В Україні така розвага також набирає популярності: троллеї вже працюють у Дніпрі, Чугуєві, Києві, Буковелі [13]. Діють компанії по будівництву та обслуговуванню зіплайнів, серед яких Мирта, Skyline, парк «Тропа» [14-16]. У середньому проєкт обійдеться, починаючи від 45 тис. доларів, проте вартість залежатиме від містобудівних умов, обмежень, класу та категорії об'єкту [17].

Сільський туризм - це специфічна форма відпочинку в приватних господарствах сільської місцевості з використанням майна та трудових ресурсів особистого селянського, підсобного або фермерського господарства, природнорекреаційних особливостей місцевості та культурної, історичної й етнографічної спадщини регіону. 
До переваг сільського туризму можна віднести:

а) гарантію охорони традиційної забудови; існує;

б) забезпечення туристам поселення там, де готельна промисловість не

в) надання роботи для місцевих ремісників;

г) підтримування місцевих традицій;

г) стимулювання безпосереднього збуту сільськогосподарської продукції;

д) сприяння усвідомленню сільськими громадами значення місцевого середовища;

е) підвищення стандарту та естетики сільських осель;

є) налагодження порозуміння між людьми села і міста;

ж) поліпшення якості життя мешканців села.

$€$ два основних види організації сільського туризму:

- здача цілком в найм сільських будиночків або кімнат у невеликих сільських готелях або котеджах;

- організація проживання відпочиваючих у сільському будинку безпосередньо в родині.

Окрім власне розміщення, туристам пропонують широкий перелік інших послуг: харчування, прийняття участі у традиційних видах сільських робіт, екскурсії, організація риболовлі, полювання, кінних, піших, моторизованих прогулянок, майстер-класів, прокат автомобілів, човнів, активно-туристичного спорядження, послуги побутового обслуговування та ін. Відповідно до цих послуг формується інфраструктура агросадиби.

На теперішній час кількісно переважають садиби базового (найнижчого) рівня з типовим продуктом сільського зеленого туризму, який складає основну частку пропозиції по Україні. Таким продуктом $є$ дві-чотири кімнати з простим меблюванням, із загальними зручностями та 3 посереднім рівнем обслуговування. Водночас набирає розвитку i пропозиція іншого виду продукту: дорогих садиб із високим рівнем обслуговування та комфорту. Через те діапазон цін на продукт сільського зеленого туризму дуже широкий - від 50 грн до 500 грн і більше на добу, залежно від якості інфраструктури та кількості надаваних послуг. Відповідно, оцінити інвестиції в розвиток особистого селянського господарства доволі складно, адже фактично розпочати цю справу можливо, використовуючи лише наявні власні ресурси і витрачаючи кошти тільки на рекламу та залучення клієнтів.

Аналіз попиту на сільський зелений туризм в Україні протягом останніх п’яти років засвідчує, що його утворюють такі основні сегменти потенційних споживачів послуг:

- мешканці промислових центрів (віддаючи перевагу такому способу відпочинку через його екологічність);

- молодь до 35 років, яка мешкає у великих містах (їх частка у сумарній кількості туристів складає понад чотири шостих);

- корінні мешканці (сприймають такий вид відпочинку як незвичайний, 
екзотичний);

- поціновувачі українських народних традицій (через принади сільського способу життя та чистоту довкілля);

- люди з низьким і середнім рівнем доходу (через доступну вартість відпочинку в сільській місцевості) [18].

Головною перевагою розвитку сільського туризму $\epsilon$ те, що він дає можливість задіяти в наданні послуг та обслуговуванні туристів багатьох членів громади, в залежності від їх можливостей і здатностей. Мається на увазі, що обслуговування туристів доволі важко здійснювати виключно силами членів однісї родини, що неминуче приводить до залучення інших місцевих фахівців до цього процесу. Наприклад, одна родина чи член громади організовує доставку туристів, хтось - екскурсійне обслуговування, хтось - навчання та майстер-класи. Поступово в орбіту туризму втягуються все більше нових учасників. Звісно, члени громади не перестають займатися власними основними видами діяльності, оскільки для більшості туризм все одно $є$ виключно додатковим видом заробітку та зайнятості.

Проте, постає гостра необхідність створення відповідної інфраструктури у вигляді забезпечення транспортної доступності, організації інформаційного забезпечення, страхування, надання послуг харчування, розміщення та прокату різноманітного обладнання та інвентарю, підготовки кадрів тощо [19; 20].

Але найбільш актуальним питанням у даному випадку є необхідність створення засобів розміщення. Рішення подібних питань можливо, як за рахунок власних коштів ОТГ, так і за рахунок залучення інвестицій, цільових кредитів і грошових позик з обов'язковим максимальним залученням до праці в усіх сферах діяльності мешканців ОТГ.

Однією з сучасних тенденцій розвитку в туризмі та його значному сегментові - готельному господарстві є орієнтація на екологічність [21]. Так, серед перспективних напрямів готельного бізнесу як для внутрішнього, так $\mathrm{i}$ для зовнішнього ринку, фахівці визначають об'єднання невеликих комфортних готелів та аналогічних засобів розміщення на природі [21; 22]. В цьому плані ОТГ, що як раз розташовані у сільській i «зеленій» зонах, $\epsilon$ найбільш відповідним місцем для створення екологічних хостелів, сімейних готелів i пансіонатів. У даному випадку подібні форми засобів розміщення вважаються привабливими, оскільки відповідають наступним вимогам: 1) розраховані на короткочасне перебування; 2) задовольняють вимоги переважної більшості туристів; 3) мають невелику вартість щодо їх створення та подальшої експлуатації, а в разі необхідності під подібні засоби розміщення можливо адаптувати вже існуючу нерухомість тощо. В рамках ОТГ можливо створити мережу подібних засобів розміщення, що будуть належати конкретній ОТГ, або можливо створити сторонню керуючу компанію, що буде створювати ці засоби розміщення в об'єднаних територіальних громадах. Основне завдання такої мережі - формування ідеології та нового іміджу відпочинку на природі, оптимізація системи продажу послуг засобів розміщення ОТГ з подальшим виходом на 
міжнародний ринок туристських послуг.

Ще одним завданням мережі подібних засобів розміщення в рамках ОТГ повинно стати створення доступних, «бюджетних» за ціновими вимогами засобів розміщення. Це обгрунтовано тим, що на даний час в Україні вимогам щодо екологічності відповідають переважно готелі високих категорій $\mathrm{i}$, як наслідок, не доступні для значної кількості споживачів готельних послуг.

Наприклад, станом на січень 2013 року Green Key (престижна міжнародна еко-сертифікація для індустрії дозвілля) надала еко-сертифікати 14 українським підприємствам готельного господарства. У м. Києві його отримали Radisson Blu Hotel, Rus Accord Hotel та Баккара Арт-готель [23]. Для отримання сертифіката Green Кеу готелям необхідно відповідати ряду екологічних вимог, починаючи від екологічних стандартів і до вимог статуту, наявності плану дій, навчання та зв'язку. Наявність еко-сертифікату Green Key показує відповідальність організації по відношенню до навколишнього середовища та суспільства.

$\mathrm{У}$ той же час для основної частини туристів найбільш запитаними $\epsilon$ «бюджетні» засоби розміщення. Саме тому можливо зазначити, що у разі створення бюджетних екологічних готелів і засобів розміщення буде здійснено інфраструктурне забезпечення розвитку інклюзивного туризму в регіоні, на чому як раз і наполягає низка науковців [24; 25].

3 метою розвитку туристської інфраструктури та задоволення попиту на «екологічні» та «бюджетні» засоби розміщення 3 боку туристів, можливо запропонувати створення мережі хостелів, які можуть бути сконцентровані за декількома напрямами [22]:

- у містах біля центрів концентрації туристських об'єктів, що дозволить задовольнити попит туристів у межах міського історико-культурного та пізнавального туризму;

- у містах біля ВНЗ та технікумів, що дозволить задовольнити попит на тимчасове розміщення студентів заочної форми навчання та пересічних туристів, оскільки зазвичай ВНЗ знаходяться в центрі міста та/або на території, яка наближена до центру міста, або в глибині районів і мікрорайонів міста;

- на межі міста, що дозволить використовувати ці хостели також у якості мотелів;

- за межами міста на територіях рекреаційного призначення, що набуває вельми актуального значення в тому разі, якщо ці рекреаційні території знаходяться під керуванням об'єднаних територіальних громад, яким необхідно самостійно займатися господарською діяльністю.

У такому разі буде отримано позитивний ефект у вигляді:

1. Буде створено мережу, щоб задовольнити попит з боку значної кількості туристів у бюджетних екологічних готелях і засобах розміщення.

2. Буде посилено інфраструктурне забезпечення розвитку інклюзивного туризму на рівні міста та регіону за рахунок урівноваження балансу «бюджетних» і «дорогих» готелів та аналогічних засобів розміщення, а також за рахунок створення готелів та аналогічних засобів розміщення там, де їх не 
було раніше.

3. Буде підвищено трудову зайнятість як фахівців, так і інших верств населення.

4. Буде підвищено прибутковість міста та регіону.

5. Буде створено позитивний імідж в країні та на міжнародному ринку інклюзивного туризму.

Таким чином, слід зазначити, що створення мережі екологічних хостелів дозволить забезпечити подальший розвиток інклюзивного туризму, здійснити посилення туристського ринку (в т.ч. і готельного ринку) України, продовжити інтеграцію до світового ринку туризму.

Висновки 3 даного дослідження та перспективи подальших розвідок. У якості висновку можливо зазначити, що фактично буде створено туристські кластери, кожен з яких може отримати спеціалізацію відповідно певному виду туризму (зелений, екологічний, сільський тощо), певному виду засобів розміщення (сімейні готелі, хостели, пансіонати і т.д.) та/або відповідно їх сполученню. 3 урахуванням того факту, що для початку буде створено умови для проживання та харчування в засобах розміщення, а також для заняття різними видами туризму в межах ОТГ, необхідно відзначити, що буде сформовано відповідний туристський напрям цілорічного функціонування.

У разі реалізації подібної стратегії розвитку об'єднаними територіальними громадами буде отримано наступні позитивні результати: буде оновлено матеріально-технічну базу та здійснено розвиток загальної інфраструктури ОТГ; буде створено нові робочі місця для мешканців ОТГ та залучено вже готових фахівців до сфери функціонування туризму. Все це приведе до підвищення прибутковості та фінансової стійкості об'єднаних територіальних громад.

\section{Перелік посилань}

1. Закон України «Про добровільне об'єднання територіальних громад» : сайт : сайт. URL: https://zakon.rada.gov.ua/laws/show/157-VIII.

2. Об'єднана територіальна громада : сайт. URL: https://uk.wikipedia.org/wiki/Об\%27єднана_територіальна_громада.

3. Писаревський I. М., Рябєв А. А., Угоднікова О. І. Конспект лекцій 3 дисципліни «Рекреалогія» для студентів 2 курсу всіх форм навчання. Харків : ХНУМГ ім. О. М. Бекетова, 2017. 93 с.

4. Абрамов В. В. Годы и тропы: К пятидесятилетию Харьковского спортивного туризма. Харьков : Кн. Рекламное агенство РА, 2000. 332 с. $367 \mathrm{c}$.

5. Абрамов В. В. Спортивний туризм : підручник. Харків : ХНАМГ, 2011.

6. Абрамов В. В. Діяльність туристської самодіяльної організації : підручник. Харків : ХНУМГ ім. О. М. Бекетова, 2020. 301 с.

7. Сєроухов Д. Туристичні тренди 2020 року: як змінюються подорожі і самі туристи : сайт. URL: https://tsn.ua/blogi/themes/tourism/turistichni-trendi2020-yak-zminyuyutsya-podorozhi-i-sami-turisti-1490427.html. 
8. Поколодна М. М., Малюк А. О. Сутність, особливості та види природничо-екологічних екскурсій. Міжнародний науковий журнал «Інтернаука». 2018. № 15. DOI: https://doi.org/10.25313/2520-2057-2018-154106.

9. Методические рекомендации по вопросам создания и информационного обеспечения экологических образовательных центров и экологических троп на особо охраняемых природных территориях: учеб.-метод. пособие для внешкольной работы учащихся средних общеобразовательных школ. Минск : В.И.З.А. ГРУПП, 2010. 90 с.

10. Организация экологической тропы : сайт. URL : http://www.istoki2006muk.narod.ru/tropa.html.

11. Троллей (Zipline) : сайт. URL: https://rope-park.com/trolley.

12. Зип-лайн : сайт. URL: https://nicko.ru/зип-лайн.

13. Zip line 'Bukovel' : сайт. URL: https://skypark.com.ua/zip-lines-byskypark/zip-line-bukovel.

14. Строительство аттракциона роллей или zipline : сайт. URL: https://mirtus.org/chto-my-stroim/stroitelstvo-attraktsiona-trollej-zipline.

15. Цены на роллер коастер зиплайн : сайт. URL: https://skyline.expert/ceny.

16. Our works : сайт. URL: https://parktropa.com/category/our-works-en.

17. Семынин М. Свой бизнес: как открыть аттракцион зиплайн : сайт. URL: https://www.openbusiness.ru/biz/business/svoy-biznes-kak-otkryt-attraktsionziplayn.

18. Дармостук Д. Г. Тенденції розвитку зеленого туризму в Україні : сайт. URL: http://www.kbuapa.kharkov.ua/e-book/tpdu/2017-2/doc/3/04.pdf.

19. Поколодна М. М. Використання інноваційних форм навчання в сфері сільського зеленого туризму. Економіка. Управління. Інновації. Серія: Економічні науки : електрон. наук. фах. вид. 2014. № 2. : сайт. URL : http://nbuv.gov.ua/UJRN/eui_2014_2_49.

20. Поколодна М. М., Писарева I. В. Розвиток туристської інфраструктури: регіональний аспект. Інфраструктура ринку. Електронний науково-практичний журнал. 2019. Випуск 28. С. 209-218 : сайт. URL : http://www.market-infr.od.ua/journals/2019/28_2019_ukr/33.pdf.

21. Рябєв А. А. Формування складових розвитку туризму в регіонах України : дис. ... канд. екон. наук : 08.00.05. Державний вищий навчальний заклад „Прикарпатський національний університет імені Василя Стефаника”. Івано-Франківськ, 2018. 234 с.

22. Рябєв А. А. Розвиток інклюзивного туризму та створення мережі екологічних хостелів. Materialy XIV Miedzynarodowej naukowi-praktycznej konferencji , «Perspektywiczne opracowania są nauką i technikami - 2018», Volume 3. Przemyśl: Nauka i studia. C. 23-27: сайт. URL: http://www.rusnauka.com/pdf/242484.pdf.

23. Мархонос С. М., Турло Н. П. Туристична сфера як фактор підвищення 
інвестиційної привабливості регіону. Економіка. Управління. Інновації. 2012. № 1. URL : http://nbuv.gov.ua/UJRN/eui_2012_1_30.

24. Оболенцева Л. В. Виявлення передумов розвитку соціального туризму в Україні. Економіка і управління національним господарством: стан, тенденції і перспективи: матеріали III Міжнародної науково-практичної конференції (2324 червня 2016 р., м. Одеса). Одеса, ОНЕУ. 2016. С. 60-61.

25. Тонкошкур М. В. Забезпечення функціонування туристичного комплексу регіону : дис. ... канд. екон. наук : 08.00.05. Державний вищий навчальний заклад „Прикарпатський національний університет імені Василя Стефаника". Івано-Франківськ, 2018. 212 с.

\section{References}

1. "Law of Ukraine "On voluntary union of territorial communities" ["Zakon Ukrainy "Pro dobrovilne obiednannia terytorialnykh hromad"], available at : https://zakon.rada.gov.ua/laws/show/157-VIII (last accessed 08.02.2020).

2. "United territorial community" ["Obiednana terytorialna hromada"], available at : https://uk.wikipedia.org/wiki/Об\%27єднана_територіальна_громада (last accessed 08.02.2020)

3. Pysarevskyi, I. M., Ryabev, A. A., Uhodnikova, O. I. (2017), "Lectures on the discipline "Recreation" for students of the 2nd year of all forms of study" ["Konspekt lektsii z dystsypliny «Rekrealohiia» dlia studentiv 2 kursu vsikh form navchannia"], Kharkiv, KhNUMG them. OM Beketova, 93 p.

4. Abramov, V. V. (2000), "Years and pathes" ["Gody $i$ tropy: K pyatidesyatiletiyu Khar'kovskogo sportivnogo turizma”, Kharkiv: Book, Advertising agency RA, $332 \mathrm{p}$.

5. Abramov, V. V. (2011), “Sports tourism: a textbook" ["Sporty`vny`j tury`zm : pidruchny`k"], KhNAMG, Kharkiv, 367 p.

6. Abramov, V. V. (2020), "Activity of an amateur tourist organization: a textbook" ["Diyal`nist` tury`sts`koyi samodiyal’noyi organizaciyi : pidruchny”k"], Kharkiv, KhNUMG them. OM Beketova, $301 \mathrm{p}$.

7. Sieroukhov, D. "2020 Travel Trends: How Travel and Tourists Change" ["Turystychni trendy 2020 roku: yak zminiuiutsia podorozhi i sami turysty"], available at : https://tsn.ua/blogi/themes/tourism/turistichni-trendi-2020-yakzminyuyutsya-podorozhi-i-sami-turisti-1490427.html (last accessed 08.02.2020).

8. Pokolodna, M. M., Malyuk, A. O. (2018), "The essence, features and types of environmental excursions" ["Sutnist, osoblivosti ta vidi prirodnicho-ekologichnih ekskursiy"], International Scientific Journal "Internauka". DOI: https://doi.org/10.25313/2520-2057-2018-15-4106.

9. "Guidelines on the creation and informational support of environmental education centers and ecological trails in specially protected natural areas: a training manual for extracurricular activities of secondary school students" (2010), ["Metodicheskie rekomendatsii po voprosam sozdaniya $i$ informatsionnogo obespecheniya ekologicheskikh obrazovatel'nykh tsentrov i ekologicheskikh trop na osobo okhranyaemykh prirodnykh territoriyakh: ucheb.-metod. posobie dlya 
vneshkol'noy raboty uchashchikhsya srednikh obshcheobrazovatel'nykh shkol"], Minsk, V.I.Z.A. GROUP, 90 p.

10. "The ecological trail creation" ["Organizatsiya ekologicheskoy tropy"], available at : http://www.istoki2006muk.narod.ru/tropa.html (last accessed 08.02.2020).

11. Trolley (Zipline), available at : https://rope-park.com/trolley/ (last accessed 08.02.2020).

12. Zipline, available at : https://nicko.ru/зип-лайн/ (last accessed 08.02.2020)

13. Zip line 'Bukovel', available at : https://skypark.com.ua/zip-lines-byskypark/zip-line-bukovel/ (last accessed 08.02.2020).

14. Construction of an attraction rolley or zipline, available at : https://mirtus.org/chto-my-stroim/stroitelstvo-attraktsiona-trollej-zipline/ (last accessed 08.02.2020).

15. Roller Coaster Zipline Prices, available at : https://skyline.expert/ceny/ (last accessed 08.02.2020).

16. Our works, available at : https://parktropa.com/category/our-works-en/ (last accessed 08.02.2020).

17. Semynin, M. (2017), Own business: how to open a zipline attraction, available at : https://www.openbusiness.ru/biz/business/svoy-biznes-kak-otkrytattraktsion-ziplayn/ (last accessed 08.02.2020).

18. Darmostuk, D. G. (2017), Green tourism development trends in Ukraine, available at : http://www.kbuapa.kharkov.ua/e-book/tpdu/2017-2/doc/3/04.pdf (last accessed 08.02.2020).

19. Pokolodna, M. M. (2014), "The innovative forms of education use in the field of rural green tourism" ["Vikoristannya InnovatsIynih form navchannya v sferI sIlskogo zelenogo turizmu"], Economy. Management. Innovations. Series: Economic sciences: electron. Science. profession. view., No. 2, available at : http://nbuv.gov.ua/UJRN/eui_2014_2_49.

20. Pokolodna, M. M., Pisareva, I. V. (2019), "Development of tourist infrastructure: regional aspect" ["Rozvitok turistskoyi Infrastrukturi: regionalniy aspekt. Infrastruktura rinku"], Market infrastructure. Electronic scientific and practical journal, No. 28, P. 209-218, available at : http://www.marketinfr.od.ua/journals/2019/28_2019_ukr/33.pdf.

21. Ryabev, A. A. (2018), "Formation of components of tourism development in the regions of Ukraine" , Abstract of Ph.D. dissertation, 08.00.05 - Productive Forces Development and Regional Economy, Vasyl Stefanyk Precarpathian National University [Formuvannya skladovy`x rozvy`tku tury`zmu $\mathrm{v}$ regionax Ukrayiny' : dy`s. ... kand. ekon. nauk : 08.00.05. Derzhavny`j vy`shhy`j navchal’ny`j zaklad „Pry`karpats`ky`j nacional`ny`j universy`tet imeni Vasy`lya Stefany`ka”], IvanoFrankivsk, Ukraine, 234 p.

22. Ryabev, A. A. (2018), "Inclusive tourism development and network of ecofriendly hostels creation" ["Rozvytok inkliuzyvnoho turyzmu ta stvorennia merezhi ekolohichnykh khosteliv"], available at : http://www.rusnauka.com/pdf/242484.pdf 
(last accessed 08.02.2020).

23. Markhonos, S. M., Turlo, N. P. (2012), "The tourist sphere as a factor of increasing the investment attractiveness of the region", available at : http://nbuv.gov.ua/UJRN/eui_2012_1_30 (last accessed 08.02.2020).

24. Obolentseva, L. V. (23-24 June 2016), "Identifying the prerequisites for the development of social tourism in Ukraine" ["Vyiavlennia peredumov rozvytku sotsialnoho turyzmu v Ukraini"], Economy and management of the national economy: state, tendencies and prospects: materials of the Third International Scientific and Practical Conference, Odesa national economic university, Odesa, P. 60-61.

25. Tonkoshur, M.V. (2018), "Ensuring the functioning of the tourist complex of the region", Abstract of Ph.D. dissertation, 08.00.05 - Productive Forces Development and Regional Economy, Vasyl Stefanyk Precarpathian National University [Zabezpechennya funkcionuvannya tury`sty`chnogo kompleksu regionu : dy`s. ... kand. ekon. nauk : 08.00.05. Derzhavny`j vy`shhy`j navchal’ny`j zaklad „Pry'karpats`ky`j nacional 'ny’j universy`tet imeni Vasy'lya Stefany'ka”], IvanoFrankivsk, Ukraine, 212 p.

\section{РЕФЕРАТИ РЕФЕРАТЫ ABSTRACTS}

\section{УДК 338.48; JEL Classification: L 830}

Рябєв А.А., Поколодна М.М., Абрамов В.В. ПІДВИЩЕННЯ ЕФЕКТИВНОСТІ ОБ'ЄДНАНИХ ТЕРИТОРІАЛЬНИХ ГРОМАД ЗА РАХУНОК ЇХ СПЕЦАЛІЗАЦЇ̈ В СФЕРІ ТУРИЗМУ ТА ГОТЕЛЬНОГО ГОСПОДАРСТВА

Mema. Визначити конкретні шляхи розвитку тих видів діяльності, які здатні забезпечити створення такої туристської інфраструктури, що буде здатна забезпечити прибутковість об'єднаних територіальних громад з урахуванням орієнтації на сільський та екологічний туризм. Результати дослідження. Автори здійснили аналіз тенденції подальшого розвитку туризму, а саме: підвищення соціальної відповідності щодо порушення екологічної рівноваги; скорочення часу та підвищення частоти відпочинку; можливість мандрувати 3 домашніми тваринами; прагнення уникнути перевантажених туристських напрямів; можливість гнучкого планування відпочинку за рахунок інформаційного забезпечення. Здійснено наголос на необхідності розвитку екологічного та сільського туризму. 3 метою розвитку екологічного та сільського туризму автори пропонують створити екологічні стежки цілорічного функціонування, що дозволять займатись різноманітними видами рекреаційних занять. Також автори пропонують створити мережі сімейних готелів, хостелів, пансіонатів, які дозволять задовольнити попит на послуги розміщення. Відповідно до цих послуг можливо буде сформувати інфраструктуру агросадиб. Практична значущість. Буде створено туристські кластери, кожен з яких 
може отримати спеціалізацію відповідно певному виду туризму (зелений, екологічний, сільський тощо), певному виду засобів розміщення (сімейні готелі, хостели, пансіонати і т.д.) та/або відповідно їх сполученню. В межах об'єднаних територіальних громад можливо буде сформувати відповідні туристські напрями цілорічного функціонування на основі створення умов для проживання та харчування в готельних закладах. Реалізація цієї стратегії розвитку об'єднаних територіальних громад дозволить отримати наступні позитивні результати: буде оновлено матеріально-технічну базу та здійснено розвиток загальної інфраструктури об'єднаних територіальних громад; буде створено нові робочі місця для мешканців об'єднаної територіальної громади та залучено вже готових фахівців до сфери функціонування туризму. Все це приведе до підвищення прибутковості та фінансової стійкості об'єднаних територіальних громад.

Ключові слова: об'єднана територіальна громада; екологічний та сільський туризм; туристська інфраструктура; готельне господарство.

УДК 338.48; JEL Classification: L 830

Рябев А.А., Поколодная М.Н., Абрамов В.В. ПОВЫШЕНИЕ ЭФФЕКТИВНОСТИ ОБЪЕДИНЕННЫХ ТЕРРИТОРИАЛЬНЫХ ОБЩИН ЗА СЧЁТ ИХ СПЕЦИАЛИЗАЦИИ В СФЕРЕ ТУРИЗМА И ГОСТИНИЧНОГО ХОЗЯЙСТВА

Цель. Определение конкретных путей развития тех видов деятельности, которые способны обеспечить создание такой туристской инфраструктуры, которая будет способна обеспечить доходность объединенных территориальных общин с учетом ориентации на сельский и экологический туризм. Результаты. Авторы рассмотрели тенденции дальнейшего развития туризма, а именно: повышение социальной ответственности за нарушение экологического равновесия; сокращение времени на отдых и повышение частоты отдыха; возможность путешествовать с домашними животными; стремление избежать перегруженных туристских направлений; возможность гибкого планирования отдыха за счет информационного обеспечения. Осуществлен упор на необходимость развития экологического и сельского туризма. С целью развития экологического и сельского туризма авторы предлагают создать экологические тропы круглогодичного функционирования, которые позволят заниматься различными видами рекреационных занятий. Также авторы предлагают создать сети семейных отелей, хостелов и пансионатов, которые позволят удовлетворить спрос на услуги размещения. На основе предлагаемых услуг можно будет сформировать инфраструктуру агроусадеб. Практическая значимость. Будут созданы туристские кластеры, каждый из которых может получить специализацию в соответствии с определенным видом туризма (зеленый, экологический, сельский и т.д.), определенным видом средств размещения (семейные гостиницы, хостелы, пансионаты) и т.д. В рамках объединенных территориальных общин можно 
будет сформировать соответствующие туристские направления круглогодичного функционирования, основой для которых станут условия для проживания и питания в предприятиях гостеприимства. Реализация этой стратегии развития объединенных территориальных общин позволит получить следующие положительные результаты: будет обновлена материальнотехническая база и осуществлено развитие общей инфраструктуры объединенных территориальных общин; будут созданы новые рабочие места для жителей объединенной территориальной общины и привлечены уже готовые специалисты в сферу функционирования туризма. Всё это приведет к повышению прибыльности и финансовой устойчивости объединенных территориальных общин.

Ключевые слова: объединенная территориальная община; экологический и сельский туризм; туристская инфраструктура; гостиничное хозяйство.

\section{UDC 338.48; JEL Classification: L 830}

Ryabev A.A., Pokolodna M.M., Abramov V.V. IMPROVEMENT OF THE EFFECTIVENESS OF THE UNITED TERRITORIAL COMMUNITIES BY THEIR SPECIALIZATION IN THE FIELD OF TOURISM AND HOTEL INDUSTRY

Purpose. The identification of specific ways for those types of activities developing that are capable of ensuring the creation of such a tourism infrastructure that will be able to ensure the profitability of the united territorial communities, taking into account the orientation towards rural and ecological tourism. Findings. The authors examined trends in the further development of tourism, namely: increasing the social responsibility for disturbing the ecological balance; reduction of time for rest and increase the frequency of rest; the ability to travel with pets; the desire to avoid overloaded tourist destinations; the possibility of flexible vacation planning due to information support. The emphasis is placed on the need for the development of ecological and rural tourism. In order to develop ecological and rural tourism, the authors propose to create ecological routes of year-round functioning that will allow to engage in various types of recreational activities. The authors also propose to create a network of family hotels, hostels and pensions, which will satisfy the demand for accommodation services. Based on the offered services, it will be possible to form the infrastructure of farmsteads. Practical value. Tourism clusters will be created, each of which can receive specialization in accordance with a certain type of tourism (green, ecological, rural, etc.), a certain type of accommodation facilities (family hotels, hostels, pension or boarding houses), etc. Within the framework of the united territorial communities, it will be possible to form appropriate tourist destinations for year-round functioning, the basis for which will be the conditions for accommodation and meals in hospitality enterprises. The implementation of this development strategy for the united territorial communities will allow to obtain the following positive results: the material and technical base will be updated and the development of the common infrastructure of the united territorial 
communities will be carried out; new jobs will be created for residents of a united territorial communities. All this changes will lead to increased profitability and financial stability of the united territorial communities.

Key words: united territorial community; ecological and rural tourism; tourism infrastructure; hotel industry.

\section{Відомості про авторів / Сведения об авторах / About the Authors}

Рябєв Антон Анатолійович - кандидат економічних наук, доцент, Харківський національний університет міського господарства ім. О.М. Бекетова, доцент кафедри туризму і готельного господарства, м. Харків, Україна; e-mail: kharkov-kruiz@ mail.ru; ORCID: 0000-0003-2220-3282. Моб. 067579-35-47.

Рябев Антон Анатольевич - кандидат экономичкских наук, доцент, Харьковский национальный университет городского хозяйства им. А.Н. Бекетова, доцент кафедры туризма и гостиничного хозяйства, г. Харьков, Украина.

Ryabev Anton - $\mathrm{PhD}$ in Economic Sciences, Associate Professor, O.M. Beketov National University of Urban Economy in Kharkiv, Associate Professor of the Department of Tourism and Hospitality.

Поколодна Марія Миколаївна - кандидат географічних наук, доцент, Харківський національний університет міського господарства ім. О.М. Бекетова, доцент кафедри туризму і готельного господарства, м. Харків, Україна; e-mail: mari.pokolodna@ukr.net ; ORCID: 0000-0003-1170-0881. Моб. 050-400-48-81.

Поколодная Мария Николаевна - кандидат географических наук, доцент, Харьковский национальный университет городского хозяйства им. А.Н. Бекетова, доцент кафедры туризма и гостиничного хозяйства, г. Харьков, Украина.

Pokolodna Mariia - PhD in Geographical Sciences, Associate Professor, O.M. Beketov National University of Urban Economy in Kharkiv, Associate Professor of the Department of Tourism and Hospitality.

Абрамов В.В. - Харківський національний університет міського господарства ім. О.М. Бекетова, доцент кафедри туризму i готельного господарства, м. Харків, Україна; e-mail: imandra67@ukr.ne; ORCID: 0000-00026954-8205. Моб. 066-964-78-39.

Абрамов В.В. - Харьковский национальный университет городского хозяйства им. А.Н. Бекетова, доцент кафедры туризма и гостиничного хозяйства, г. Харьков, Украина.

Abramov V.V. - O.M. Beketov National University of Urban Economy in Kharkiv, Associate Professor of the Department of Tourism and Hospitality. 